\title{
Pseudoruegeria aquimaris gen. nov., sp. nov., isolated from seawater of the East Sea in Korea
}

Correspondence

Jung-Hoon Yoon

jhyoon@kribb.re.kr

\author{
Jung-Hoon Yoon, Soo-Young Lee, So-Jung Kang, Choong-Hwan Lee \\ and Tae-Kwang Oh
}

Korea Research Institute of Bioscience and Biotechnology (KRIBB), PO Box 115, Yusong, Taejon, Korea

\begin{abstract}
A Gram-negative, non-motile, rod-shaped bacterial strain, SW- $255^{\top}$, was isolated from seawater from Hwajinpo, on the coast of the East Sea, Korea, and subjected to a polyphasic taxonomic study. Strain SW-255 $5^{\top}$ grew optimally at $\mathrm{pH} 7.0-8.0$ and $37^{\circ} \mathrm{C}$ in the presence of $2 \%(\mathrm{w} / \mathrm{v}) \mathrm{NaCl}$. It contained $\mathrm{Q}-10$ as the predominant ubiquinone and $\mathrm{C}_{18: 1} \omega 7 \mathrm{c}$ as the major fatty acid. The DNA $\mathrm{G}+\mathrm{C}$ content was 67.0 mol\%. A neighbour-joining phylogenetic tree based on 16S rRNA gene sequences showed that strain $S W-255^{\top}$ is phylogenetically closely related to the genera Ruegeria and Silicibacter of the Alphaproteobacteria. The levels of 16S rRNA gene sequence similarity between strain $\mathrm{SW}-255^{\top}$ and the type strains of Ruegeria atlantica and two Silicibacter species were in the range 95.8-96.2\%. A phylogenetic tree based on gyrB sequences showed that strain $\mathrm{SW}-255^{\top}$ forms a distinct evolutionary lineage within the Alphaproteobacteria.

Differential phenotypic properties, polar lipid profiles and DNA G+C contents, together with the phylogenetic distinctiveness, suggest that strain $\mathrm{SW}-255^{\top}$ should be distinguished from the members of the genera Ruegeria and Silicibacter. On the basis of the phenotypic, chemotaxonomic and phylogenetic data, strain $\mathrm{SW}-255^{\top}$ represents a novel genus and species, for which the name Pseudoruegeria aquimaris gen. nov., sp. nov. is proposed. The type strain of Pseudoruegeria aquimaris is $\mathrm{SW}-255^{\top}\left(=\mathrm{KCTC} 12737^{\top}=\mathrm{JCM} 13603^{\top}\right)$.
\end{abstract}

The genus Ruegeria was created from the reclassification of Agrobacterium atlanticum, Agrobacterium gelatinovorum and Roseobacter algicola (Uchino et al., 1998). 16S rRNA gene sequence analyses have since shown that Ruegeria gelatinovorans and Ruegeria algicola have phylogenetic positions that are independent of Ruegeria atlantica, the type species of the genus (González et al., 2003; Lee et al., 2005). Ruegeria gelatinovorans and Ruegeria algicola have subsequently been reclassified as Thalassobius gelatinovorus (Arahal et al., 2005) and Marinovum algicola (i.e. in a novel genus; Martens et al., 2006). The related genus Silicibacter was proposed by Petursdottir \& Kristjansson (1997) with a single species, Silicibacter lacuscaerulensis; another Silicibacter species, Silicibacter pomeroyi, has since been described (González et al., 2003). Here we describe a bacterial strain, SW- $255^{\mathrm{T}}$, which is phylogenetically closely related to Ruegeria atlantica, S. lacuscaerulensis and $S$. pomeroyi. The aim of the present study was to determine the exact taxonomic position of strain $\mathrm{SW}-255^{\mathrm{T}}$ by means of a polyphasic characterization that included determination of

The GenBank/EMBL/DDBJ accession number for the $16 \mathrm{~S}$ rRNA gene sequence of strain $\mathrm{SW}-255^{\top}$ is DQ675021, and those for the gyrB sequences of strain SW-255 ${ }^{\top}$, S. lacuscaerulensis KCTC $2953^{\mathrm{T}}$, S. pomeroyi DSM $15171^{\top}$ and Ruegeria atlantica KCTC $12424^{\top}$ are EF010915-EF010918, respectively. phenotypic and chemotaxonomic properties and a detailed phylogenetic analysis based on 16S rRNA gene sequences.

Strain SW $-255^{\mathrm{T}}$ was isolated from seawater from Hwajinpo on the coast of the East Sea, Korea, by means of the standard dilution plating technique at $25^{\circ} \mathrm{C}$ on marine agar 2216 (MA; Difco). The type strains of Ruegeria atlantica, S. lacuscaerulensis and S. pomeroyi were used as reference strains for the phenotypic and fatty acid analyses; Ruegeria atlantica KCTC $12424^{\mathrm{T}}$ and S. lacuscaerulensis KCTC $2953^{\mathrm{T}}$ were obtained from the Korean Collection for Type Cultures, Taejon, Korea. S. pomeroyi DSM $15171^{\mathrm{T}}$ was obtained from the Deutsche Sammlung von Mikroorganismen und Zellkulturen (Braunschweig, Germany). The morphological, physiological and biochemical characteristics of strain $\mathrm{SW}-255^{\mathrm{T}}$ were investigated using routine cultivation on $\mathrm{MA}$ at $37^{\circ} \mathrm{C}$. The cell morphology was examined by using light microscopy (E600; Nikon) and transmission electron microscopy. The presence of flagella was determined using transmission electron microscopy (CM-20; Philips) with cells from cultures growing exponentially. For transmission electron microscopic observation, cells were negatively stained with $1 \%(\mathrm{w} / \mathrm{v})$ phosphotungstic acid and the grids were examined after air drying. Growth under anaerobic conditions was determined after incubation in a Forma 
anaerobic chamber on MA and on MA supplemented with nitrate, both of which had been prepared anaerobically using a nitrogen atmosphere. Growth in the absence of $\mathrm{NaCl}$ was investigated using trypticase soy broth prepared according to the formula of the Difco medium except that no $\mathrm{NaCl}$ was used. Growth at various $\mathrm{NaCl}$ concentrations was investigated in marine broth 2216 (Difco) or trypticase soy broth (Difco). Growth at various temperatures $\left(4-55^{\circ} \mathrm{C}\right)$ was measured on MA. Catalase and oxidase activities and the hydrolysis of casein, starch and Tweens 20, 40, 60 and 80 were determined as described by Cowan \& Steel (1965). The hydrolysis of hypoxanthine, tyrosine and xanthine was tested on MA using the substrate concentrations described by Cowan \& Steel (1965). The hydrolysis of aesculin, gelatin and urea and nitrate reduction were investigated as described previously (Lanyi, 1987), with the modification that artificial seawater was used in the preparation of the media. The artificial seawater contained $\left(1^{-1}\right.$ distilled water) $23.6 \mathrm{~g} \mathrm{NaCl}, 0.64 \mathrm{~g} \mathrm{KCl}, 4.53 \mathrm{~g}$ $\mathrm{MgCl}_{2} \cdot 6 \mathrm{H}_{2} \mathrm{O}, 5.94 \mathrm{~g} \mathrm{MgSO}_{4} .7 \mathrm{H}_{2} \mathrm{O}$ and $1.3 \mathrm{~g} \mathrm{CaCl}_{2} .2 \mathrm{H}_{2} \mathrm{O}$ (Bruns et al., 2001). $\mathrm{H}_{2} \mathrm{~S}$ production was tested as described previously (Bruns et al., 2001). Susceptibility to antibiotics was detected on MA plates by using antibiotic discs with the following amounts: polymyxin B (100 U), streptomycin $(50 \mu \mathrm{g})$, penicillin $\mathrm{G}(20 \mathrm{U})$, chloramphenicol $(100 \mu \mathrm{g})$, ampicillin $(10 \mu \mathrm{g})$, cephalothin $(30 \mu \mathrm{g})$, gentamicin $(30 \mu \mathrm{g})$, novobiocin $(5 \mu \mathrm{g})$ and tetracycline $(30 \mu \mathrm{g})$. Acid production from carbohydrates was determined as described by Leifson (1963). The utilization of various substrates for growth was determined as described by Baumann \& Baumann (1981) using supplementation with $2 \%(\mathrm{v} / \mathrm{v})$ Hutner's mineral salts solution (Cohen-Bazire et al., 1957) and a $1 \%(\mathrm{v} / \mathrm{v})$ vitamin solution (Staley, 1968). Other physiological and biochemical tests were performed with the API 20E and API ZYM systems (bioMérieux).

Cell biomass for respiratory lipoquinone analysis and for DNA extraction was obtained from cultivation in marine broth 2216 at $37^{\circ} \mathrm{C}$. Chromosomal DNA was isolated and purified according to the method described by Yoon et al. (1996), with the exception that RNase T1 was used in combination with RNase A to minimize contamination with RNA. The $16 \mathrm{~S}$ rRNA gene was amplified by using a PCR with two universal primers, as described previously (Yoon et al., 1998). Sequencing of the amplified 16S rRNA gene and phylogenetic analysis were performed as described by Yoon et al. (2003). PCR amplification of the DNA gyrase B subunit gene $(g y r B)$ was performed by using two primers, UP-1 and UP-2r, according to a method described previously (Yamamoto \& Harayama, 1995). The PCR product was purified with the QIAquick PCR purification kit (Qiagen). Sequencing of the purified PCR product was performed with an Applied Biosystems automatic DNA sequencer (model 3130) using two primers, as described by Yamamoto \& Harayama (1995). Alignment of the sequences was carried out with the CLUSTAL W software (Thompson et al., 1994). Gaps at the $5^{\prime}$ and $3^{\prime}$ ends of the alignment were omitted from further analysis. Evolutionary distance matrices were calculated by using the algorithm of Jukes \& Cantor (1969) with the DNADIST program. A phylogenetic tree was constructed by using the neighbour-joining method (Saitou \& Nei, 1987) in the PHYLIP package (Felsenstein, 1993). The stability of the relationships was assessed by means of a bootstrap analysis based on 1000 resamplings of the neighbour-joining dataset, using the programs SEQBOOT, DNADIST, NEIGHBOR and CONSENSE of the PHYLIP package.

Respiratory lipoquinones were analysed as described by Komagata \& Suzuki (1987) using reversed-phase HPLC. For cellular fatty acid analysis, cell mass of strain $\mathrm{SW}-255^{\mathrm{T}}$, Ruegeria atlantica KCTC $12424^{\mathrm{T}}$, S. lacuscaerulensis KCTC $2953^{\mathrm{T}}$ and S. pomeroyi DSM $15171^{\mathrm{T}}$ was harvested from MA plates after cultivation for 3 days at $37,20,45$ and $30^{\circ} \mathrm{C}$, respectively. Fatty acids were extracted and fatty acid methyl esters were prepared according to the standard protocol of the MIDI/Hewlett Packard Microbial Identification System (Sasser, 1990). Polar lipids were extracted according to the procedures described by Minnikin et al. (1984) and were identified by two-dimensional TLC followed by spraying with the appropriate detection reagents (Minnikin et al., 1984; Komagata \& Suzuki, 1987). The presence of phosphatidylcholine was tested by spraying with Dragendorff's reagent (Sigma). The DNA G $+\mathrm{C}$ content was determined by the method of Tamaoka \& Komagata (1984), with the modification that the DNA was hydrolysed and the resultant nucleotides were analysed by reversed-phase HPLC.

Morphological, cultural, physiological and biochemical characteristics of strain $\mathrm{SW}-255^{\mathrm{T}}$ are given in the genus and species descriptions (see below) and in Table 1. The almost-complete 16S rRNA gene sequence of strain SW$255^{\mathrm{T}}$ determined in this study comprised $1421 \mathrm{nt}$, representing approximately $96 \%$ of the Escherichia coli $16 \mathrm{~S}$ rRNA gene sequence. In the neighbour-joining phylogenetic tree based on $16 \mathrm{~S}$ rRNA gene sequences, strain SW $-255^{\mathrm{T}}$ was part of the clade comprising Ruegeria atlantica and the two Silicibacter species, with a bootstrap resampling value of $53.8 \%$ (Fig. 1). Strain SW- $255^{\mathrm{T}}$ exhibited $16 \mathrm{~S}$ rRNA gene sequence similarity values of $95.8,96.0$ and $96.2 \%$ with respect to the type strains of Ruegeria atlantica, $S$. lacuscaerulensis and S. pomeroyi, respectively. The $16 \mathrm{~S}$ rRNA gene sequence similarity values between strain SW$255^{\mathrm{T}}$ and other species used in the phylogenetic analysis were below $95.6 \%$. The gyrB sequences of strain SW $-255^{\mathrm{T}}$, Ruegeria atlantica KCTC $12424^{\mathrm{T}}$, S. lacuscaerulensis KCTC $2953^{\mathrm{T}}$ and S. pomeroyi DSM $15171^{\mathrm{T}}$ determined in this study each comprised $1146 \mathrm{nt}$. Strain $\mathrm{SW}-255^{\mathrm{T}}$ exhibited gyrB sequence similarity values of $76.2,81.8$ and $80.1 \%$ with respect to Ruegeria atlantica KCTC $12424^{\mathrm{T}}$, S. lacuscaerulensis KCTC $2953^{\mathrm{T}}$ and S. pomeroyi DSM $15171^{\mathrm{T}}$, respectively. The gyrB sequence similarity between $S$. lacuscaerulensis KCTC $2953^{\mathrm{T}}$ and S. pomeroyi DSM $15171^{\mathrm{T}}$ was $85.4 \%$.

The predominant respiratory lipoquinone detected in strain SW- $255^{\mathrm{T}}$ was Q-10 (at a peak area ratio of approximately $95 \%)$. The fatty acid profile of strain SW- $255^{\mathrm{T}}$ comprised 
Table 1. Differential phenotypic characteristics of strain $\mathrm{SW}-255^{\top}$ and members of the genera Ruegeria and Silicibacter

Taxa: 1, strain SW- $255^{\mathrm{T}} ; 2$, Ruegeria atlantica $1480^{\mathrm{T}}$ [data from Rüger \& Höfle (1992) unless indicated]; 3, S. lacuscaerulensis [Petursdottir \& Kristjansson (1997) unless indicated]; 4, S. pomeroyi [González et al. (2003) unless indicated]. All four taxa are positive for catalase, oxidase, alkaline phosphatase, esterase (C4), esterase lipase (C8), leucine arylamidase and the utilization of succinate (data for the type strain of $S$. lacuscaerulensis from this study) and pyruvate. All are negative for growth at $4{ }^{\circ} \mathrm{C}$, Gram-staining, indole and $\mathrm{H}_{2} \mathrm{~S}$ production, lipase (C14), valine arylamidase, cystine arylamidase, trypsin, $\alpha$-chymotrypsin, $\alpha$-galactosidase, $\beta$-glucuronidase, $\alpha$-glucosidase, $\beta$-glucosidase, $\alpha$-mannosidase, $\alpha$-fucosidase, arginine dihydrolase, lysine decarboxylase, ornithine decarboxylase, hydrolysis of casein (data for the type strains of $S$. lacuscaerulensis and S. pomeroyi from this study), starch (data for the type strain of S. lacuscaerulensis from this study), Tween 80 (data for the type strains of Ruegeria atlantica and S. lacuscaerulensis from this study) and urea (data for the type strains of S. lacuscaerulensis and S. pomeroyi from this study) and acid production from lactose (data for the type strains of S. lacuscaerulensis and $S$. pomeroyi from this study). +, Positive; -, negative; w, weak.

\begin{tabular}{|c|c|c|c|c|}
\hline Characteristic & 1 & 2 & 3 & 4 \\
\hline Motility & - & - & - & + \\
\hline Optimum temperature for growth $\left({ }^{\circ} \mathrm{C}\right)$ & 37 & $20-30$ & 45 & 30 \\
\hline \multicolumn{5}{|l|}{ Growth at: } \\
\hline $37^{\circ} \mathrm{C}$ & + & - & + & + \\
\hline $50^{\circ} \mathrm{C}$ & - & - & + & - \\
\hline Nitrate reduction & - & + & + & $-\star$ \\
\hline Hydrolysis of gelatin & - & - & - & + \\
\hline \multicolumn{5}{|l|}{ Utilization of: } \\
\hline L-Arabinose & + & - & $-*$ & $-*$ \\
\hline D-Cellobiose & + & + & $+^{*}$ & $-*$ \\
\hline D-Galactose & + & + & $+^{*}$ & $-*$ \\
\hline D-Glucose & + & + & - & + \\
\hline Maltose & + & + & $-{ }^{\star}$ & $-*$ \\
\hline D-Mannose & + & + & $+^{*}$ & $-*$ \\
\hline Sucrose & + & + & $-*$ & $-*$ \\
\hline Salicin & + & - & $-*$ & $-*$ \\
\hline D-Trehalose & + & + & $-*$ & $-*$ \\
\hline D-Xylose & + & + & $-*$ & $+^{*}$ \\
\hline Acetate & + & + & - & + \\
\hline Citrate & + & + & - & + \\
\hline L-Glutamate & - & + & $-*$ & $-*$ \\
\hline \multicolumn{5}{|l|}{ Acid production from: } \\
\hline D-Glucose & + & + & $-*$ & $-*$ \\
\hline L-Arabinose & + & + & $-*$ & $-*$ \\
\hline D-Fructose & + & - & $+^{*}$ & $-*$ \\
\hline Maltose & + & + & $-*$ & $-*$ \\
\hline D-Mannitol & + & - & $-*$ & $-*$ \\
\hline Sucrose & + & + & $-*$ & $-*$ \\
\hline D-Xylose & - & + & $-*$ & $-*$ \\
\hline \multicolumn{5}{|l|}{ Susceptibility to: } \\
\hline Penicillin G & + & - & + & $-*$ \\
\hline Chloramphenicol & + & + & + & $-*$ \\
\hline \multicolumn{5}{|l|}{ API ZYM test results* } \\
\hline Acid phosphatase & + & - & - & - \\
\hline Naphthol-AS-BI-phosphohydrolase & $\mathrm{w}$ & - & $\mathrm{w}$ & - \\
\hline$\beta$-Galactosidase & + & - & + & - \\
\hline$N$-Acetyl- $\beta$-glucosaminidase & + & - & - & - \\
\hline Major polar lipids* ${ }^{*}$ & PG, DPG, PE, PL, GL & PC, PG, DPG, PE, PL & PG, DPG, PE & PC, PG, PE, AL \\
\hline DNA G $+C$ content $(\mathrm{mol} \%)$ & 67.0 & 55 & 66.2 & $67.9-68.1$ \\
\hline
\end{tabular}

${ }^{\star}$ Data for the type strain from this study.

$\dagger$ AL, Unidentified aminolipid; DPG, diphosphatidylglycerol; GL, unidentified glycolipid; PC, phosphatidylcholine; PE, phosphatidylethanolamine; PG, phosphatidylglycerol; PL, unidentified phospholipid. 


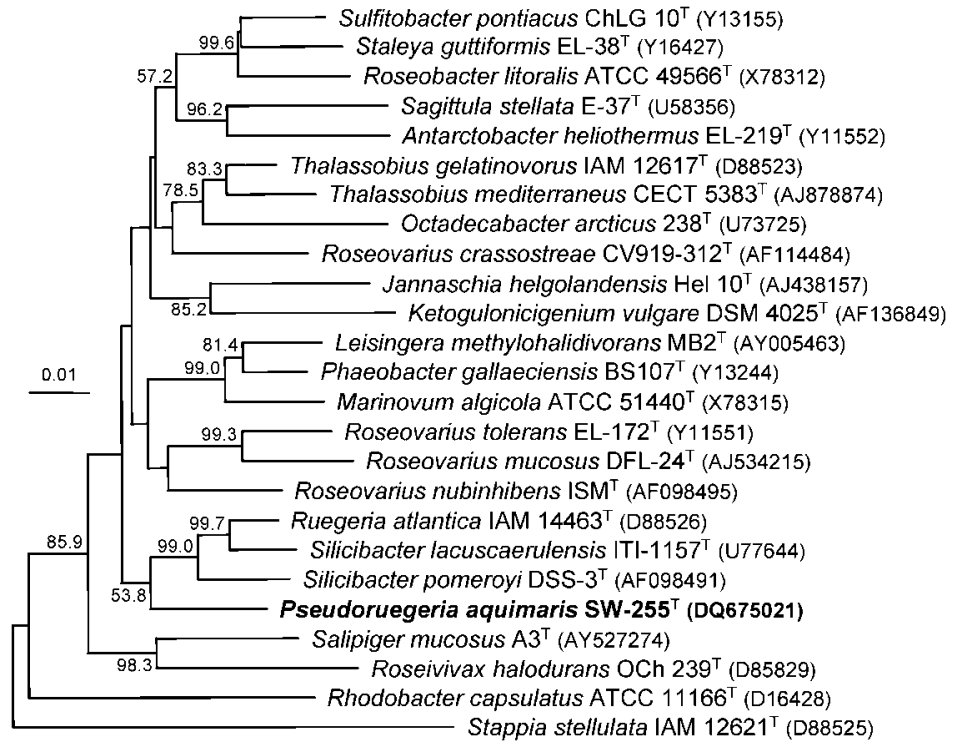

Fig. 1. Neighbour-joining phylogenetic tree, based on 16S rRNA gene sequences, showing the positions of strain SW- $255^{\top}$ and some related taxa. Bootstrap values (expressed as percentages of 1000 replications) $>50 \%$ are shown at branch points. Stappia stellulata IAM $12621^{\top}$ was used as an outgroup. Bar, 0.01 substitutions per nucleotide position. major amounts of unsaturated, straight-chain and hydroxy fatty acids; the major fatty acid was $\mathrm{C}_{18: 1} \omega 7 c(72.9 \%)$ (Table 2). This fatty acid profile was similar to those of Ruegeria atlantica and the two Silicibacter species, although there were differences in the proportions of some fatty acids, perhaps because of differences in cultivation conditions (González et al., 2003; Table 2). The major polar lipids detected in strain $\mathrm{SW}-255^{\mathrm{T}}$ were phosphatidylglycerol, diphosphatidylglycerol, phosphatidylethanolamine, an unidentified phospholipid and an unidentified glycolipid (Fig. 2). The major polar lipids detected in Ruegeria atlantica KCTC $12424^{\mathrm{T}}$, S. lacuscaerulensis KCTC $2953^{\mathrm{T}}$ and S. pomeroyi DSM $15171^{\mathrm{T}}$ are shown in Fig. 2 and Table 1. The DNA G $+\mathrm{C}$ content of strain $\mathrm{SW}-255^{\mathrm{T}}$ was $67.0 \mathrm{~mol} \%$.

In the phylogenetic analysis based on 16S rRNA gene sequences, strain $\mathrm{SW}-255^{\mathrm{T}}$ was most closely related to Ruegeria atlantica and the two Silicibacter species. Strain SW $-255^{\mathrm{T}}$ is relatively similar to Ruegeria atlantica in terms of phenotypic properties, as shown in Table 1 , but it is clearly distinguishable on the basis of the difference in DNA $\mathrm{G}+\mathrm{C}$ content. It can also be differentiated from Ruegeria atlantica on the basis of the phylogenetic relationships among strain SW-255 ${ }^{\mathrm{T}}$, Ruegeria atlantica and the two Silicibacter species (Fig. 1). Strain $\mathrm{SW}-255^{\mathrm{T}}$ is distinguishable from the two Silicibacter species by phenotypic differences (Table 1). The neighbour-joining tree based on $\operatorname{gyr} B$ sequences showed that strain $\mathrm{SW}-255^{\mathrm{T}}$ forms a phylogenetic lineage that is independent of those of Ruegeria atlantica, S. lacuscaerulensis and S. pomeroyi (Fig. 3). Strain $\mathrm{SW}-255^{\mathrm{T}}$ is also distinguishable from the type strains of Ruegeria atlantica, S. lacuscaerulensis and S. pomeroyi in terms of the polar lipid patterns (Fig. 2, Table 1). In particular, strain $\mathrm{SW}-255^{\mathrm{T}}$ differs from Ruegeria atlantica in that phosphatidylcholine is absent, and it differs from $S$. pomeroyi in that diphosphatidylglycerol is present as a major polar lipid and phosphatidylcholine is absent (Fig. 2).
Strain SW $-255^{\mathrm{T}}$ is also distinguishable from S. lacuscaerulensis by the presence of an unidentified phospholipid and an unidentified glycolipid (Fig. 2). Accordingly, strain SW-

Table 2. Cellular fatty acid compositions (\%) of strain SW$255^{\top}$ and related type strains

Strains: 1, strain SW- $255^{\mathrm{T}}$; 2, Ruegeria atlantica KCTC $12424^{\mathrm{T}} ; 3$, S. lacuscaerulensis KCTC $2953^{\mathrm{T}}$; 4 , S. pomeroyi DSM $15171^{\mathrm{T}}$. Fatty acids that constituted $<0.5 \%$ in all strains were omitted. ECL, Equivalent chain length; ND, not detected.

\begin{tabular}{|c|c|c|c|c|}
\hline Fatty acid & 1 & 2 & 3 & 4 \\
\hline \multicolumn{5}{|l|}{ Straight-chain fatty acids } \\
\hline $\mathrm{C}_{10: 0}$ & ND & 3.0 & 3.0 & 3.1 \\
\hline $\mathrm{C}_{12: 0}$ & 0.5 & 3.7 & 3.3 & 1.3 \\
\hline$C_{16: 0}$ & 1.4 & 3.0 & 8.2 & 7.9 \\
\hline $\mathrm{C}_{17: 0}$ & 0.9 & ND & 0.7 & 0.3 \\
\hline $\mathrm{C}_{18: 0}$ & 6.6 & 0.8 & 3.7 & 2.3 \\
\hline \multicolumn{5}{|l|}{ Unsaturated fatty acids } \\
\hline $\mathrm{C}_{18: 1} \omega 5 c$ & 0.8 & $\mathrm{ND}$ & ND & ND \\
\hline $\mathrm{C}_{18: 1} \omega 7 c$ & 72.9 & 53.0 & 52.8 & 54.2 \\
\hline $\mathrm{C}_{20: 1} \omega 7 c$ & 0.9 & ND & 0.5 & 0.5 \\
\hline \multicolumn{5}{|l|}{ Hydroxy fatty acids } \\
\hline $\mathrm{C}_{10: 0} 3-\mathrm{OH}$ & 2.9 & 0.5 & 1.0 & 0.5 \\
\hline $\mathrm{C}_{12: 0} 3-\mathrm{OH}$ & ND & 6.5 & 4.9 & 5.7 \\
\hline $\mathrm{C}_{16: 0} 2-\mathrm{OH}$ & 0.6 & 10.8 & 0.4 & 7.7 \\
\hline $\mathrm{C}_{18: 1} 2-\mathrm{OH}$ & ND & 1.6 & $\mathrm{ND}$ & ND \\
\hline 11-Methyl $\mathrm{C}_{18: 1} \omega 7 c$ & 2.8 & 15.9 & 3.4 & 15.0 \\
\hline cyclo $\mathrm{C}_{19: 0} \omega 8 \mathrm{c}$ & 5.9 & ND & 16.0 & ND \\
\hline Summed feature $3^{*}$ & 0.7 & 0.2 & 0.7 & 0.3 \\
\hline Unknown fatty acid (ECL 11.799) & 2.8 & 0.2 & 0.3 & 0.1 \\
\hline
\end{tabular}

${ }^{\star}$ Summed features are groups of two or three fatty acids that could not be separated by GLC with the MIDI system. Summed feature 3 contained $\mathrm{C}_{16: 1} \omega 7 c$ and/or iso- $\mathrm{C}_{15: 0} 2-\mathrm{OH}$. 


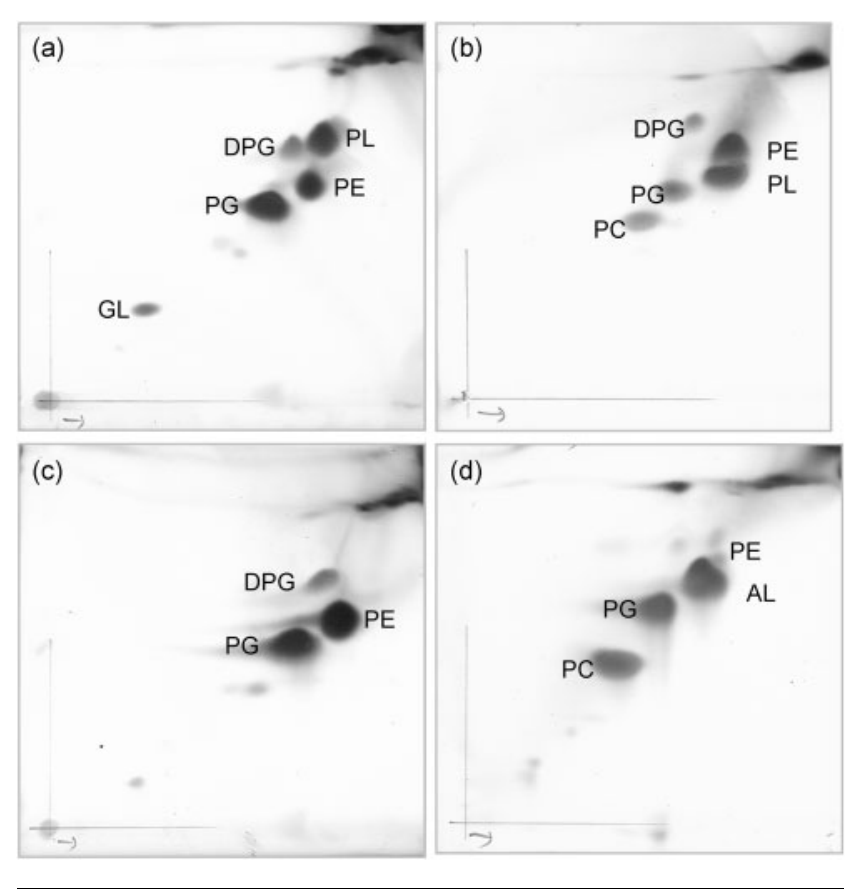

Fig. 2. Two-dimensional thin-layer chromatograms of the polar lipids of strain SW-255 ${ }^{\top}$ (a), Ruegeria atlantica KCTC $12424^{\top}$ (b), S. lacuscaerulensis KCTC $2953^{\top}$ (c) and S. pomeroyi DSM $15171^{\top}$ (d). Abbreviations: AL, unidentified aminolipid; DPG, diphosphatidylglycerol; GL, unidentified glycolipid; PC, phosphatidylcholine; PE, phosphatidylethanolamine; PG, phosphatidylglycerol; PL, unidentified phospholipid.

$255^{\mathrm{T}}$ should be classified within a novel genus and species distinct from the genera Ruegeria and Silicibacter. On the basis of the data presented, strain $\mathrm{SW}-255^{\mathrm{T}}$ represents a novel genus and species within the class Alphaproteobacteria, for which the name Pseudoruegeria aquimaris gen. nov., sp. nov. is proposed.

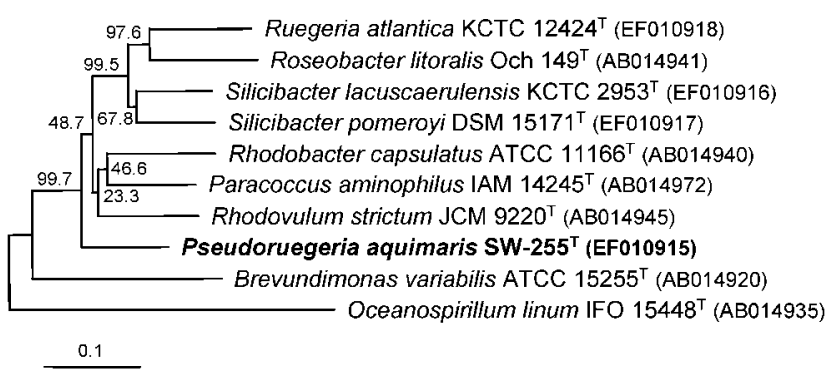

Fig. 3. Neighbour-joining phylogenetic tree, based on gyrB sequences, showing the positions of strain $\mathrm{SW}-255^{\top}$ and some related taxa. Bootstrap values (expressed as percentages of 1000 replications) are shown at branch points. Oceanospirillum linum IFO $15448^{\top}$ was used as an outgroup. Bar, 0.1 substitutions per nucleotide position.

\section{Description of Pseudoruegeria gen. nov.}

Pseudoruegeria (Pseu.do.rue.ge'ri.a. Gr. adj. pseudes false; N.L. fem. n. Ruegeria a bacterial generic name; N.L. fem. $n$. Pseudoruegeria false Ruegeria).

Cells are Gram-negative, aerobic rods $(0.3-0.8 \times$ $1.0-8.0 \mu \mathrm{m})$. The predominant ubiquinone is Q-10. The major fatty acid is $\mathrm{C}_{18: 1} \omega 7 c$. The DNA G $+\mathrm{C}$ content is $67.0 \mathrm{~mol} \%$ (HPLC). The type species is Pseudoruegeria aquimaris.

\section{Description of Pseudoruegeria aquimaris sp. nov.}

Pseudoruegeria aquimaris (a.qui.ma'ris. L. n. aqua water; L. gen. n. maris of the sea; N.L. gen. n. aquimaris of the water of the sea).

Cells are Gram-negative rods $(0.3-0.8 \times 1.0-8.0 \mu \mathrm{m})$. Colonies on MA are circular to slightly irregular, raised, smooth, greyish yellow in colour and $2.0-3.0 \mathrm{~mm}$ in diameter after 3 days incubation at $37^{\circ} \mathrm{C}$. Growth occurs at 15 and $49^{\circ} \mathrm{C}$, but not at 10 or $50^{\circ} \mathrm{C}$. Optimal pH for growth is between 7.0 and 8.0; growth occurs at $\mathrm{pH} 5.5$, but not at $\mathrm{pH}$ 5.0. Growth occurs in the presence of $8 \%$ $(w / v) \mathrm{NaCl}$, but not in the absence of $\mathrm{NaCl}$ or in the presence of more than $9 \%(\mathrm{w} / \mathrm{v}) \mathrm{NaCl}$. Anaerobic growth does not occur on MA or on MA supplemented with nitrate. Aesculin and hypoxanthine are hydrolysed, but xanthine, L-tyrosine and Tweens 40 and 60 are not. DFructose and L-malate are utilized as carbon and energy sources, but benzoate and formate are not. Acid is produced from D-cellobiose, D-galactose, D-mannose, melibiose, Lrhamnose, D-trehalose and myo-inositol, but not from Dmelezitose, D-raffinose, D-ribose or D-sorbitol. Susceptible to ampicillin, carbenicillin, cephalothin, gentamicin, kanamycin, neomycin, novobiocin, oleandomycin, polymyxin $\mathrm{B}$, streptomycin and tetracycline, but not to lincomycin. The predominant ubiquinone is $\mathrm{Q}-10$. The major fatty acid ( $>10 \%$ of total fatty acids) is $\mathrm{C}_{18: 1} \omega 7 c$. The major polar lipids are phosphatidylglycerol, diphosphatidylglycerol, phosphatidylethanolamine, an unidentified phospholipid and an unidentified glycolipid. The DNA G $+\mathrm{C}$ content of the type strain is $67.0 \mathrm{~mol} \%$ (determined by HPLC). Other phenotypic characteristics are given in Table 1.

The type strain, SW $-255^{\mathrm{T}}\left(=\right.$ KCTC $\left.12737^{\mathrm{T}}=\mathrm{JCM} 13603^{\mathrm{T}}\right)$, was isolated from seawater from the beach at Hwajinpo, East Sea, Korea.

\section{Acknowledgements}

This work was supported by the 21C Frontier Program of Microbial Genomics and Applications (grant MG05-0401-2-0) from the Ministry of Science and Technology of the Republic of Korea. 


\section{References}

Arahal, D. R., Macián, M. C., Garay, E. \& Pujalte, M. J. (2005). Thalassobius mediterraneus gen. nov., sp. nov., and reclassification of Ruegeria gelatinovorans as Thalassobius gelatinovorus comb. nov. Int J Syst Evol Microbiol 55, 2371-2376.

Baumann, P. \& Baumann, L. (1981). The marine Gram-negative eubacteria: genera Photobacterium, Beneckea, Alteromonas, Pseudomonas, and Alcaligenes. In The Prokaryotes, pp. 1302-1331. Edited by M. P. Starr, H. Stolp, H. G. Trüper, A. Balows \& H. G. Schlegel. Berlin: Springer.

Bruns, A., Rohde, M. \& Berthe-Corti, L. (2001). Muricauda ruestringensis gen. nov., sp. nov., a facultatively anaerobic, appendaged bacterium from German North Sea intertidal sediment. Int J Syst Evol Microbiol 51, 1997-2006.

Cohen-Bazire, G., Sistrom, W. R. \& Stanier, R. Y. (1957). Kinetic studies of pigment synthesis by nonsulfur purple bacteria. $J$ Cell Comp Physiol 49, 25-68.

Cowan, S. T. \& Steel, K. J. (1965). Manual for the Identification of Medical Bacteria. London: Cambridge University Press.

Felsenstein, J. (1993). PHYLIP (phylogeny inference package), version 3.5. Department of Genome Sciences, University of Washington, Seattle, USA.

González, J. M., Covert, J. S., Whitman, W. B., Henriksen, J. R., Mayer, F., Scharf, B., Schmitt, R., Buchan, A., Fuhrman, J. A. \& other authors (2003). Silicibacter pomeroyi sp. nov. and Roseovarius nubinhibens sp. nov., dimethylsulfoniopropionate-demethylating bacteria from marine environments. Int J Syst Evol Microbiol 53, 1261-1269.

Jukes, T. H. \& Cantor, C. R. (1969). Evolution of protein molecules. In Mammalian Protein Metabolism, vol. 3, pp. 21-132. Edited by $\mathrm{H}$. N. Munro. New York: Academic Press.

Komagata, K. \& Suzuki, K. (1987). Lipid and cell wall analysis in bacterial systematics. Methods Microbiol 19, 161-203.

Lanyi, B. (1987). Classical and rapid identification methods for medically important bacteria. Methods Microbiol 19, 1-67.

Lee, K.-B., Liu, C.-T., Anzai, Y., Kim, H., Aono, T. \& Oyaizu, H. (2005). The hierarchical system of the 'Alphaproteobacteria': description of Hyphomonadaceae fam. nov., Xanthobacteraceae fam. nov. and Erythrobacteraceae fam. nov. Int J Syst Evol Microbiol 55, 1907-1919.

Leifson, E. (1963). Determination of carbohydrate metabolism of marine bacteria. I Bacteriol 85, 1183-1184.

Martens, T., Heidorn, T., Pukall, R., Simon, M., Tindall, B. J. \& Brinkhoff, T. (2006). Reclassification of Roseobacter gallaeciensis Ruiz-Ponte et al. 1998 as Phaeobacter gallaeciensis gen. nov., comb. nov., description of Phaeobacter inhibens sp. nov., reclassification of Ruegeria algicola (Lafay et al. 1995) Uchino et al. 1998 as Marinovum algicola gen. nov., comb. nov., and emended descriptions of the genera Roseobacter, Ruegeria and Leisingera. Int J Syst Evol Microbiol 56, 1293-1304.
Minnikin, D. E., O'Donnell, A. G., Goodfellow, M., Alderson, G., Athalye, M., Schaal, A. \& Parlett, J. H. (1984). An integrated procedure for the extraction of bacterial isoprenoid quinones and polar lipids. J Microbiol Methods 2, 233-241.

Petursdottir, S. K. \& Kristjansson, J. K. (1997). Silicibacter lacuscaerulensis gen. nov., sp. nov., a mesophilic moderately halophilic bacterium characteristic of the Blue Lagoon geothermal lake in Iceland. Extremophiles 1, 94-99.

Rüger, H.-J. \& Höfle, M. G. (1992). Marine star-shaped-aggregateforming bacteria: Agrobacterium atlanticum sp. nov.; Agrobacterium meteori sp. nov.; Agrobacterium ferrugineum sp. nov., nom. rev.; Agrobacterium gelatinovorum sp. nov., nom. rev.; and Agrobacterium stellulatum sp. nov., nom. rev. Int J Syst Bacteriol 42, 133-143.

Saitou, N. \& Nei, M. (1987). The neighbor-joining method: a new method for reconstructing phylogenetic trees. Mol Biol Evol 4, 406-425.

Sasser, M. (1990). Identification of bacteria by gas chromatography of cellular fatty acids. MIDI Technical Note 101. Newark, DE: MIDI Inc.

Staley, J. T. (1968). Prosthecomicrobium and Ancalomicrobium: new prosthecate freshwater bacteria. J Bacteriol 95, 1921-1942.

Tamaoka, J. \& Komagata, K. (1984). Determination of DNA base composition by reverse-phase high-performance liquid chromatography. FEMS Microbiol Lett 25, 125-128.

Thompson, J. D., Higgins, D. G. \& Gibson, T. J. (1994), CLUSTAL W: improving the sensitivity of progressive multiple sequence alignment through sequence weighting, position-specific gap penalties and weight matrix choice. Nucleic Acids Res 22, 4673-4680.

Uchino, Y., Hirata, A., Yokota, A. \& Sugiyama, J. (1998). Reclassification of marine Agrobacterium species: proposals of Stappia stellulata gen. nov., comb. nov., Stappia aggregata sp. nov., nom. rev., Ruegeria atlantica gen. nov., comb. nov., Ruegeria gelatinovora comb. nov., Ruegeria algicola comb. nov., and Ahrensia kieliense gen. nov., sp. nov., nom. rev. J Gen Appl Microbiol 44, 201-210.

Yamamoto, S. \& Harayama, S. (1995). PCR amplification and direct sequencing of $g y r B$ genes with universal primers and their application to the detection and taxonomic analysis of Pseudomonas putida strains. Appl Environ Microbiol 61, 1104-1109.

Yoon, J.-H., Kim, H., Kim, S.-B., Kim, H.-J., Kim, W. Y., Lee, S. T., Goodfellow, M. \& Park, Y.-H. (1996). Identification of Saccharomonospora strains by the use of genomic DNA fragments and rRNA gene probes. Int J Syst Bacteriol 46, 502-505.

Yoon, J.-H., Lee, S. T. \& Park, Y.-H. (1998). Inter- and intraspecific phylogenetic analysis of the genus Nocardioides and related taxa based on 16S rRNA gene sequences. Int J Syst Bacteriol 48, 187-194.

Yoon, J.-H., Kang, K. H. \& Park, Y.-H. (2003). Psychrobacter jeotgali sp. nov., isolated from jeotgal, a traditional Korean fermented seafood. Int J Syst Evol Microbiol 53, 449-454. 